\title{
Does public pension impact migrant workers' nutrition: evidence from urban pension insurance in China
}

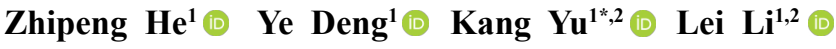 \\ ${ }^{1}$ College of Economics and Management, Zhejiang A\&F University, 311300, Hangzhou, China. E-mail: yukang888@163.com. "Corresponding author. \\ ${ }^{2}$ Research Academy for Rural Revitalization of Zhejiang Province, Zhejiang A\&F University, 311300, Hangzhou, China.
}

ABSTRACT: Based on the data of "employment and food demand of urban migrant workers", this paper empirically analyzed the impact of urban pension insurance on the nutritional intake structure of migrant workers. The results showed that participating in urban pension insurance can change the nutritional intake structure of migrant workers. Additionally, fat and protein replace carbohydrate as the main nutrition sources for migrant workers. After controlling the income and labor intensity of migrant workers and other factors, urban pension insurance has a positive effect on the intake of fat and protein of migrant workers for they increase by $13.5 \%$ and $8.8 \%$ respectively. There is no significant effect on the intake of carbohydrates of migrant workers. The calorie intake of migrant workers increases by $6.8 \%$ accounting for the change of nutritional intake structure. Endogenous and robustness tests showed that the above conclusions are robust. Heterogeneity analysis showed that there is no significant difference in the effect of urban pension insurance on calorie intake of migrant workers in different income levels and age groups.

Key words: urban pension insurance, migrant workers, calorie intake, nutritional structure, uncertainty.

A previdência pública impacta a nutrição de trabalhadores migrantes: evidências do seguro de pensão urbana na China

RESUMO: Este artigo usa os dados da pesquisa de "Emprego e demanda alimentar dos trabalhadores migrantes urbanos" para analisar empiricamente o impacto do seguro patrimonial urbano na estrutura de ingestão nutricional dos trabalhadores migrantes. O estudo constatou que: o seguro-pensão urbano mudou a estrutura de ingestão nutricional dos trabalhadores migrantes. Gordura e proteina substituíram os carboidratos e se tornaram a principal fonte de nutrição dos trabalhadores migrantes. Depois de controlar fatores como a renda e a intensidade do trabalho dos trabalhadores migrantes, o seguro de pensão urbana aumentou significativamente a ingestão de gordura e proteina dos trabalhadores migrantes em 13,5\% e 8,8\%, respectivamente, enquanto a ingestão de carboidratos dos trabalhadores migrantes não foi afetada. Significativamente afetado. A transformação da estrutura de ingestão nutricional dos trabalhadores migrantes aumentou sua ingestão calórica em 6,8\%. Os testes de endogenia e robustez mostram que as conclusões acima são robustas. A análise de heterogeneidade mostra que não há diferença significativa no efeito do seguro previdenciário urbano sobre o aumento da ingestão de calorias para trabalhadores migrantes de diferentes níveis de renda e diferentes grupos etários.

Palavras-chave: seguro previdenciário urbano, trabalhadores migrantes, ingestão calórica, estrutura nutricional, incerteza.

\section{INTRODUCTION}

In recent decades, China's rural residents have been moving to cities and towns, gradually forming a special group of migrant workers. Migrant workers have become a major force in urbanization. According to 2019 Statistical Bulletin on the National Economic and Social Development of China, In 2019, up to 291 million migrant workers accounted for $66 \%$ of urban employment. However, the social security level of migrant workers is far lower than that of urban workers (LI \& LI, 2007). For example, According to the 2017 Statistical Bulletin on human Resources and Social Security Development of China, in 2017, the participation rate of urban pension insurance for migrant workers is only $21.6 \%$, compared with $17.0 \%$ in our paper's sample. Migrant workers are engaged in labor-intensive industries such as construction, catering service and low-end manufacturing that urban residents are unwilling to engage in (LU \& LI, 2009). Compared with urban residents, migrant workers are faced with disadvantages such as lower income level, higher labor intensity and worse working environment. With the increase of working hours, the health status of migrant workers is gradually worse than that of urban residents (LI et 
al., 2018a). Furthermore, the problem of insufficient nutritional intake of migrant workers is obvious. In the sample of this paper, $85 \%$ of the calorie intake of male migrant workers in heavy manual labor is lower than the recommended intake of $3000 \mathrm{kcal}$ (CHINESE SOCIETY OF NUTRITION, 2014). In addition, the study showed that nutrient intake of residents is closely related to labor productivity and social economic development (STRAUSS, 1986). If the migrant workers in long-term nutrition level fail to meet the labor intensity needs, they will easily have diseases for malnutrition or accidental health damage and suffering injuries. Injury or illness plays a vital role for migrant workers to fall into poverty (HAN et al., 2017). However, the relation of social security and household food consumption remains a controversial issue in previous studies. In China, the study showed that participation in new rural pension insurance can reduce the future uncertainty faced by residents and promote nutrition consumption in rural households (ZHENG \& ZHONG, 2016). However, the study of HUANG (2016) showed that household consumption of residents aged 45-60 years old participating in the new rural insurance is squeezed to a certain extent due to their pension contributions, with the most significant impact on family food expenditure. Therefore, the relationship between urban pension insurance and the nutritional intake of migrant workers is worth exploring.

No doubt the most direct and effective way to improve nutrition and structure is to increase disposable income for residents. For poverty eradication and malnutrition, whether nutrition demand is related to income elasticity with obvious policy implications. Based on the above analysis, the income elasticity of nutritional demand is a widespread concern and some studies have reported that Chinese residents' income elasticity of nutritional demand is much higher than zero (MENG et al., 2009; ZHENG \& HENNEBERRY, 2012; LI \& CHEN, 2017; LI et al., 2018b). According to national urban survey data, MENG et al.(2009) reported that while urban household income and expenditure increased, urban residents' per capita calorie intake did not increase from 1986 to 2000 . In particular, mid- and low-income families' total calorie consumption has not risen, but declined. Why doesn't income increase improve nutrition intake? According to MENG et al. (2009), one is that since the reform and opening, the market-oriented reform in the fields of education, medical care, elderly care and employment have brought uncertainty to the income and expenditure of resident families, which has increased the precautionary savings of families, particularly low- and middle-income families, and reduced the consumption of food. LI (2012) reported that household income risk significantly reduced calorie, fat, and protein intake by rural residents. This showed that while nutritional demand has income elasticity, if families face great future uncertainty, their income growth is still insufficient to improve the nutritional intake of low- and middle-income residents.

Based on data from the China Nutrition and Health Survey(CHNS) and inspired by the link between income uncertainty and nutrient intake, researchers use completely different methods to investigate the effect of the new rural cooperative medical system (NCMS) on rural residents' nutrition intake and draw completely different conclusions (MA et al., 2011; MA \& ZHANG, 2011; WANG et al., 2019). Some indicated that NCMS significantly improves the intake of calories, protein and carbohydrate per capita in rural households, but it has no significant effect on fat intake (MA et al., 2011; WANG et al., 2019). Since calories come mainly from carbohydrate and fat in food, grains are the main source of carbohydrates (CHINESE SOCIETY OF NUTRITION, 2014), it means that NCMS primarily promotes staple food consumption, and then improves rural residents' calorie intake. Others indicated that NCMS significantly improves the intake of calories, fat and protein per capita in rural households, but it has no significant effect on carbohydrate intake (MA \& ZHANG, 2011), indicating that NCMS increases the intake of meat, eggs, aquatic products and other foods instead of staple foods.

From existing results, some issues still deserve further study. First, existing nutrition intake research objects are mainly rural residents and urban residents, and studies on migrant workers' nutrition intake are insufficient. Second, there are still few and controversial studies on the relationship between social insurance and nutrient intake structure, especially migrant workers' social insurance and nutrient intake structure. As migrant workers are middle- and low-income groups in cities, social insurance participation is low. Social insurance may be an important factor affecting migrant workers' nutritional intake structure. Third, physical activity's intensity, height and weight are vital factors that cannot be neglected. However, in previously relevant studies, both variables are not well controlled and important explanatory variables may be omitted. For example, some studies did not control the intensity and height and weight of the physical activity of migrant workers (MA et al., 2011; MA \& ZHANG, 
2011); WANG et al. (2019) did not control the variables of the height and weight of the elderly in rural areas; MENG et al. (2009), LI \& CHEN (2017), LI et al. (2018) did not control the height and weight of urban residents.

The rest of this paper is arranged as follows: Second, putting forward hypotheses through theoretical analysis; Third, describing data sources and main statistical methods; Fourth is the results analysis, including the descriptive statistics, the main estimation results, heterogeneity analysis, endogeneity discussion and robustness test; Five is the discussion and conclusion.

\section{Theoretical analysis and hypothesis}

China's public pension system includes three main pension schemes: the Urban Employees' Pension Plan (UEPP), the New Rural Pension Scheme (NRPS) and the Urban Residents Pension Scheme (URPS). Among them, the UEPP is insured for various urban enterprises and their employees, urban flexible employment personnel and individual industrial and commercial households (including rural registered permanent residence personnel). At present, the system of combining social co-ordination funds with individual accounts is applied in the UEPP. According to Notice of the State Council on Issuing the Pilot Plan for Improving the Urban Social Security System of China, migrant workers employed in urban enterprises pay $8 \%$ of their total wages to their individual accounts, and urban enterprises pay about $20 \%$ of their total wages to their social pooling accounts. According to Decision of the State Council on Improving the Basic Pension Insurance System for Enterprise Employees of China, for individual employed farmers, the payment amount is $20 \%$ of the average salary of local employees in the previous year, of which $8 \%$ is recorded in individual accounts and $12 \%$ is included in the social pooling fund. Migrant workers who are required to pay a cumulative contribution for 15 years may retire at the place of the current pension insurance relationship and apply for pension.

Urban pension insurance has both positive and negative effects on the nutritional consumption of migrant workers. Conversely, pension insurance can significantly reduce future uncertainty facing migrant workers, then reduce their preventive savings (HUBBARD et al., 1995), then promote current consumption (including food consumption). Migrant workers, on the other hand, have to pay a considerable amount of fees to participate in pension insurance, thus squeezing their disposable income and reducing current consumption. Chinese residents' food consumption and nutrition structure can be roughly divided into poverty period, food and clothing transition period, structural adjustment period, and nutritional health period (LI, 2007). During the transition period, the food-based structure began to diversify and food consumption per capita increased while meat, eggs, aquatic products and other food consumption increased continuously. During the period of structural adjustment, the food structure remained diversified and food consumption per capita began to decline (LI, 2007). The study of LI (2020) shows that, In China, the food consumption and nutrition structure of migrant workers have been out of the poverty period and the transition period of food and clothing, and it is entering into the structural adjustment period. The positive effects of urban pension insurance will not increase grain consumption. Simultaneously, as grain is essential for survival, the negative effects of urban pension insurance are not expected to reduce food consumption, a major source of carbohydrates.

Hypothesis 1: Urban pension insurance will neither increase nor decrease the carbohydrate intake of migrant workers.

During the adjustment period of food consumption and nutritional structure, with declining per capita grain consumption, animal food consumption shows a rapid increase (LI, 2007). The positive effect of urban pension insurance is expected to promote meat, eggs, aquatic products and other food for migrant workers, thereby increasing the intake of fat and protein. Because of the high price of protein-rich foods (such as beef and aquatic products) and the negative effect of urban pension insurance, urban pension insurance may restrict migrant workers' effective food demand, preventing migrant workers from increasing or even decreasing fat and protein intake.

Hypothesis 2: The impact of urban pension insurance on the fat and protein intake of migrant workers is uncertain.

Calories mainly come from carbohydrate, fat and protein, among them carbohydrates are the most economical and the most important source of calories, with carbohydrates supplying 55\%-65\% of calories consumed. Fat is also a major source of calories, with $30-35 \%$ of calories consumed in fatsupplied physical activity. Protein's main function is not to supply calories, but insufficient protein intake can cause symptoms such as fatigue, weight loss, anemia, decreased immunity, and anti-stress ability (CHINESE SOCIETY OF NUTRITION, 2014). Therefore, hypothesis 1 and hypothesis 2 form the following hypothesis 3 . 
Hypothesis 3: The impact of urban pension insurance on calorie intake of migrant workers is uncertain.

\section{Data and methods Data source}

The data were from the 2014 Survey of "Employment and Food Demand of Urban Migrant Workers" conducted by China Agricultural University. The survey areas included Beijing, Guangdong, Shandong, Sichuan and Zhejiang. The method of stratified sampling and random sampling were adopted for sample sampling, which includes three stages: First, provincial capitals and cities (counties and districts) with a high influx of migrant workers were selected from the five confirmed sample provinces (cities). Secondly, the selected number of research samples in various industries was based on the proportion of industry structure of migrant workers. Finally, different sampling methods were adopted according to the characteristics of different industries. For the industry of construction, manufacturing, partial wholesale and retail industry, where living quarters of migrant workers was adjacent to their workplace, the investigators firstly made a contact with the selected enterprise, and the employer would provide a list to randomly select 10-20 samples, then the investigators went to the enterprises to investigate migrant workers. In addition, for the industry of transportation, storage, postal service, accommodation and catering industry, resident service industry and other industries, living quarters of migrant workers was not adjacent to their workplaces, the researchers had to go to the corresponding industry cluster to find out migrant workers engaged in the corresponding industry for investigation. A total of 3,994 migrant workers were employed in manufacturing industry, construction industry, transportation and warehousing, postal industry, wholesale and retail industry, accommodation and catering industry, residential service, repair and other service industries, accounting for $36.9 \%, 25 \%, 3.6 \%, 10.1 \%, 9.3 \%$ and $15.1 \%$, respectively. This was basically consistent with the 2014 Migrant Workers Monitoring Survey Report on the distribution proportion of the industry structure of migrant workers in cities, which indicated that the sample of this paper had strong representativeness. The questionnaire survey covered the interviewees' basic demographic information, labor intensity, monthly average income, social security and other working conditions, and their daily meals in a day and additional meals, which provided data support for the study of the relation between urban pension insurance and the nutritional intake structure of migrant workers. Referring to MENG et al. (2009) study, samples with daily calorie intake below $800 \mathrm{kcal}$ and above 10000 $\mathrm{kcal}$, as well as samples with missing data of breakfast and dinner, were excluded in this paper, and the final effective sample number were 3315 .

\section{Dependent variables}

Nutrient intake structure refers to the intake of carbohydrates, fats, and proteins, three types of nutrients that are metabolized in the body to produce the calories needed to maintain human activity. The measurement of nutrient intake mainly includes the following two steps: First, Based on basic meal information of migrant workers in a day, it includes breakfast, lunch, dinner, extra meals and snacks, quantity and weight of various foods. The staple food covers rice, steamed bread, steamed buns, pies and dumplings, and dishes include names of dishes, composition of ingredients and meat types. Meals are divided into rice, noodles, meat (pork, beef, lamb, chicken, duck, etc.), eggs (eggs, duck eggs, goose eggs, quail eggs), milk (milk, yogurt), aquatic products (fish , shrimp, crab, shellfish, etc.) and grains (corn, millet, beans, potato, soybean milk, etc.). Second, Migrant workers' daily intake of carbohydrates, fat, protein and calorie is calculated based on the standard conversion coefficient provided by the 2002 China Food Composition Table. This paper excludes samples with daily intake of calories below 800 kcal and above 10,000 kcal (MENG et al., 2009). The effective sample is 3,315 , except for missing breakfast and dinner data, such as, wheat contains 317 kilocalories, 11.9 grams of protein, 1.3 grams of fat, and 75.2 grams of carbohydrates per 100 grams of wheat. The conversion formula is as follows:

$$
\mathrm{N}_{\mathrm{k}}=\sum_{\mathrm{j}=1} P_{\mathrm{kg}} X_{\mathrm{j}}
$$

Where $\mathrm{N}_{K}$ is the intake of Category $k$ nutrients, and $\mathrm{P}_{\mathrm{kj}}$ is the amount of category k nutrients contained in each unit of Category $\mathrm{j}$ food, including carbohydrates, protein, fat and calories. This value refers to the food composition table of China. $X_{j}$ is the $\mathrm{j}_{\text {th }}$ food consumption.

\section{Independent variables \\ Urban pension insurance}

In this study, respondents were asked "which insurance do you have" to determine whether they participated in urban pension insurance. The binary choice variable was used to measure, 1 represented migrant workers to participate in 
urban pension insurance, 0 represented they not to participate. The result showed the number of migrant workers who participated and did not participate was $549(16.6 \%)$ and 2,766 (83.4\%), respectively.

\section{Control variables}

Food prices. As there was no local food price data, following the study of Meng et al. (2009), regional dummy variables were used to control regional food prices $(1=$ Beijing; 2 = Guangdong; 3 = Shandong; 4 = Sichuan; 5 = Zhejiang).

Labor intensity was recorded based on the occupational type of migrant workers $(1=$ very light manual labor, sitting work, such as office workers, watch repairers, etc.; 2 = light manual labor, standing work, such as sales clerks, laboratory technicians, teachers, etc.; 3 = moderate physical labor, such as students, drivers, electricians; $4=$ heavy physical labor, such as farmers, dancers, steel workers, athletes, etc. $5=$ extremely heavy physical labor, such as stevedores, loggers, miners, stonemasons, etc. In this paper, extremely light physical labor and light physical labor are classified into light physical labor, heavy physical labor and extremely heavy physical labor are classified into heavy physical labor. Further, the labor intensity is coded into three levels of classification variables, 1 represents light manual labor, 2 represents medium manual labor, and 3 represents heavy manual labor.

In addition, based on previous studies, we controlled demographic characteristics, namely Body Mass Index (BMI), which is the ratio of weight $(\mathrm{kg})$ to height $(\mathrm{m})$ squared; gender, male is 1 , female is 0 . Age is also a related factor of nutrient intake. In order to reveal the non-linear effect of age on nutrient intake, age and age square were controlled. Different levels of education may have different consumption habits and nutritional knowledge, thus affecting food consumption choices (WANG \& HE, 2016). The education level is coded into three levels of categorical variables: 1 represents junior high school and below, 2 represents senior high school or junior college, and 3 represents undergraduate and above.

\section{Statistical Methods}

Firstly, in order to explore the dietary quality of migrant workers, the nutritional intake and recommended intake of migrant workers were compared in the form of graphics portfolio. Secondly, multiple linear regression (OLS) was used to analyze the impact of urban pension insurance on the nutritional intake structure of migrant workers. The basic model was set as follows:

$$
\ln C_{j i}=\beta_{0}+\gamma D_{i}+\beta_{1} \ln X_{1 i}+\sum_{k=2} \beta_{k} X_{k i}+u_{i}
$$

Among them, $\mathrm{C}_{\mathrm{ji}}$ refers to the daily average intake of $\mathrm{j}$ nutrients, namely, carbohydrate, fat, protein and calorie, of $i$ migrant workers. $D_{i}$ represents whether $\mathrm{i}$ migrant workers participate in urban pension insurance; $X_{1 \mathrm{i}}$ is the monthly average income of i migrant workers; $X_{\mathrm{ki}}$ represents the other control variable. Then, further discussing heterogeneity of influence of nutrient intake structure from the aspects of income, age and other urban pension insurance of migrant workers, finally, discussing the possible endogenous problem, and uses the Propensity Score Matching (PSM) method further estimate the effects of the urban pension insurance, to test the robustness of OLS estimation results.

\section{RESULTS}

\section{Descriptive statistics}

Table 1 reported the descriptive statistical results of nutrient intake, urban pension insurance and control variables of migrant workers. Among them, the participation of rural migrant workers in urban pension insurance is only $17.0 \%$, the average monthly income of 3340.43 yuan, engaged in light, medium and heavy manual labor, the proportion of migrant workers were $16 \%, 57 \%, 27 \%$ respectively. The average body mass index was 22.23, male migrant workers accounted for $58 \%$, the average age of 35.84, and the level of education junior middle school and below, high school or college, bachelor degree and above the average ratio of $66 \%, 30 \%$ and $4 \%$ respectively.

\section{Regression analysis}

Model (2) is estimated by a robust OLS test method and the estimated results are reported in Table 2. Table 2 's second column shows that controlled factors such as the monthly average income and labor intensity of migrant workers showed no significant difference in migrant workers' carbohydrate intake regardless of whether or not they participate in urban pension insurance, which verifies hypothesis 1: urban pension insurance neither increase nor decrease the carbohydrate intake of migrant workers.

Table 2's third and fourth columns show that urban pension insurance significantly improves migrant workers' fat and protein intake. Specifically, migrant workers participate in urban pension insurance, fat and protein intake increases by $13.5 \%$ and $8.8 \%$ respectively compared to non-participating migrant workers, indicating that urban pension 
Table 1 - Descriptive statistics of the study sample.

\begin{tabular}{|c|c|c|c|c|}
\hline Variables & & Mean & Unit & Std. Err. \\
\hline \multirow{4}{*}{ Dependent variables } & Carbohydrate & 305.75 & g/day & 122.07 \\
\hline & Fat & 65.06 & $\mathrm{~g} /$ day & 53.36 \\
\hline & Protein & 67.27 & g/day & 30.61 \\
\hline & Calorie & 2069.40 & $\mathrm{kcal} /$ day & 811.30 \\
\hline Independent variables & Urban pension insurance & 0.17 & $\%$ & 0.37 \\
\hline \multirow{15}{*}{ Control variables } & Monthly income (RMB) & 3340.43 & RMB & 2859.41 \\
\hline & Light manual labour & 0.16 & $\%$ & 0.37 \\
\hline & Middle manual labour & 0.57 & $\%$ & 0.50 \\
\hline & Heavy manual labour & 0.27 & $\%$ & 0.44 \\
\hline & BMI & 22.23 & $\mathrm{Kg} / \mathrm{m}^{2}$ & 3.06 \\
\hline & Gender & 0.58 & $\%$ & 0.49 \\
\hline & Age & 35.84 & year & 11.10 \\
\hline & Middle school and below & 0.66 & $\%$ & 0.47 \\
\hline & High school or junior college & 0.30 & $\%$ & 0.46 \\
\hline & Bachelor and above & 0.04 & $\%$ & 0.19 \\
\hline & Beijing & 0.19 & $\%$ & 0.39 \\
\hline & Guang Dong & 0.20 & $\%$ & 0.40 \\
\hline & Shan Dong & 0.20 & $\%$ & 0.40 \\
\hline & Si Chuan & 0.20 & $\%$ & 0.40 \\
\hline & Zhe Jiang & 0.21 & $\%$ & 0.41 \\
\hline
\end{tabular}

Notes: BMI in table 1 represent the weight $(\mathrm{Kg})$ and height $(\mathrm{m})$ squared of the sample migrant workers.

insurance has a positive effect on migrant workers' fat and protein intake. which showed in hypothesis 2 , the positive effect of urban pension insurance on migrant workers' fat and protein intake exceeds the negative effect.

As compared with migrant workers who did not participate in the urban pension insurance, those participated had no obvious effect on carbohydrates (hypothesis 1). However, it has a significant positive effect on protein and fat intake (hypothesis 2). Therefore, participating in the urban pension insurance has positive influence on calorie intake in hypothesis 3 . The results in the fifth column of table 2 shows that, at the $1 \%$ significance level, compared with the migrant workers who did not participate in the urban pension insurance, the calorie intake of migrant workers who participated was significantly increased by $6.8 \%$. Namely, participating in the urban pension insurance obviously promotes the calorie intake of migrant workers in hypothesis 3 .

The above results showed that urban pension insurance changes the nutritional intake structure of migrant workers, and fat and protein replace carbohydrates as the main source of nutritional growth for migrant workers, which means urban pension insurance promotes meat, eggs, aquatic products and other foods excluding staple food consumption.

Based on the three controlled variables, namely monthly average income, labor intensity, and BMI, the study showed that average monthly income has a significant positive effect on migrant workers' intake of calories, fat, and proteins, while it has no significant effect on carbohydrate intake. The intake of calorie, carbohydrates and fat from migrant workers with heavy manual labor was significantly higher than that of migrant workers with light manual labor, but no significant difference in protein intake could be explained by the high price of protein-rich food that suppressed their food demand. BMI has no significant effect on migrant workers' nutrient intake.

\section{Heterogeneity analysis}

Heterogeneity analysis of migrant workers in different income groups

The empirical results of the previous model (2) show that urban pension insurance has a 
Table 2 - Estimated results of model (2).

\begin{tabular}{|c|c|c|c|c|}
\hline Variables & Carbohydrate & Fat & Protein & Calorie \\
\hline Urban pension insurance & $0.026(0.021)$ & $0.135^{* * *}(0.043)$ & $0.088^{* * *}(0.021)$ & $0.068^{* * *}(0.019)$ \\
\hline Log of average & $-0.019(0.018)$ & $0.222^{* * *}(0.039)$ & $0.075^{* * *}(0.019)$ & $0.051^{* * *}(0.016)$ \\
\hline Middle manual labour & $0.012(0.021)$ & $0.008(0.045)$ & $0.011(0.021)$ & $0.006(0.018)$ \\
\hline Heavy manual labour & $0.072^{* * *}(0.025)$ & $0.115^{* *}(0.056)$ & $0.034(0.026)$ & $0.061^{* * *}(0.022)$ \\
\hline BMI & $0.003(0.002)$ & $-0.002(0.005)$ & $0.001(0.003)$ & $0.002(0.002)$ \\
\hline Gender & $0.164^{* * *}(0.017)$ & $0.132^{* * *}(0.036)$ & $0.131^{* * *}(0.017)$ & $0.147^{* * *}(0.015)$ \\
\hline Age & $0.019^{* * *}(0.004)$ & $0.014(0.009)$ & $0.017^{* * *}(0.004)$ & $0.016^{* * *}(0.004)$ \\
\hline Age squared & $-0.000^{* * *}(0.000)$ & $-0.000^{* *}(0.000)$ & $-0.000^{* * *}(0.000)$ & $-0.000^{* * *}(0.000)$ \\
\hline High school or junior college & $0.000(0.017)$ & $0.088^{* *}(0.035)$ & $0.043^{* * *}(0.016)$ & $0.021(0.015)$ \\
\hline Bachelor and above & $-0.023(0.038)$ & $0.147^{*}(0.087)$ & $0.080^{* *}(0.040)$ & $0.047(0.034)$ \\
\hline Guangdong & $-0.020(0.023)$ & $0.596^{* * *}(0.051)$ & $0.136^{* * *}(0.024)$ & $0.142^{* * *}(0.021)$ \\
\hline Shandong & $-0.023(0.021)$ & $-0.208^{* * *}(0.055)$ & $-0.002(0.023)$ & $-0.044^{* *}(0.020)$ \\
\hline Sichuan & $-0.206^{* * *}(0.024)$ & $0.477^{* * *}(0.048)$ & $-0.012(0.023)$ & $-0.010(0.020)$ \\
\hline Zhejiang & $-0.114^{* * *}(0.019)$ & $0.029(0.050)$ & $-0.067^{* * *}(0.023)$ & $-0.087^{* * *}(0.019)$ \\
\hline Constant term & $5.279^{* * *}(0.156)$ & $1.574^{* * *}(0.335)$ & $3.069^{* * *}(0.158)$ & $6.698^{* * *}(0.137)$ \\
\hline Observations & 3315 & 3315 & 3315 & 3315 \\
\hline$R$-squared & 0.102 & 0.130 & 0.071 & 0.094 \\
\hline
\end{tabular}

Notes: Robust standard errors are put into parentheses; ${ }^{* * *}$ indicates significance at $1 \%$ level, ${ }^{* *}$ at $5 \%$ level and ${ }^{*}$ at $10 \%$ level.

promoting effect on migrant workers' consumption. However, migrant workers' consumer behavior at different income levels has different responses to pension insurance. High-income migrant workers are able to handle future uncertainties; therefore their reaction to pension insurance is not sensitive. On the contrary, migrant workers with low-incomes are less able to cope with future uncertainties, and have a stronger desire for urban pension insurance, thus, urban pension insurance has different impacts on migrant workers consumption in different income groups. However, the various food consumption of migrant workers may not have a significant heterogeneity, especially the food consumption that guarantees the basic survival of migrant workers. In this paper, the average monthly income less than or equal to 2200 yuan is classified as low-income, the average monthly income more than or equal to 2200 yuan less than or equal to 4000 yuan is defined as middle-income, and the average monthly income more than 4000 yuan are high income.

$\mathrm{D}_{1 \mathrm{i}}=1$ means middle-income group or high income group, and $\mathrm{D}_{1 \mathrm{i}}=0$ means low-income group. The model is set as:

$\ln C_{j i}=\beta_{0}+\gamma D_{i}+\delta D_{i} \cdot D_{1 i}+\beta_{1} \ln X_{1 i}+\sum_{k=2} \beta_{k} X_{k i}+v_{i}$

Ine estimated results ${ }_{k=2}$ are reported in table 3. On the basis of the estimated results of carbohydrate, fat, protein and calorie, the interaction with urban pension insurance and the middle-income as well as high-income groups is not statistically significant, which indicates that there is no significant heterogeneity in the impact of urban pension insurance on the nutritional intake of migrant workers in different income groups. It is due in migrant workers' income and consumption levels are low, and most of migrant workers engage in heavy manual work, which generally leads to insufficient nutrition intake in migrant workers. The proportion of actual calorie intake of migrant workers in different income groups (low-income, middle-income and high income group) is high and similar, $68 \%, 73 \%$, and $70 \%$ respectively. Therefore, it is necessary for different income groups of migrant workers to improve nutritional intake.

Heterogeneity analysis of migrant workers in different age groups

Age has a strong restriction on the participation of urban pension insurance for migrant workers, Chinese pension insurance system for urban workers stipulates that those who participate in the scheme must pay contributions for 15 years in total before they can receive their pension upon retirement. Pension may be received at the place of employment where the accumulative contributions have reached 10 years for those employees participates in urban

Ciência Rural, v.51, n.12, 2021. 
Table 3 - Estimation results of model (3).

\begin{tabular}{|c|c|c|c|c|}
\hline Variables & Carbohydrate & Fat & Protein & Calorie \\
\hline Urban pension insurance & $\begin{array}{l}-0.004 \\
(0.040)\end{array}$ & $\begin{array}{l}0.199^{* *} \\
(0.081)\end{array}$ & $\begin{array}{l}0.095^{* *} \\
(0.039)\end{array}$ & $\begin{array}{l}0.083^{* *} \\
(0.034)\end{array}$ \\
\hline $\begin{array}{l}\text { Urban pension insurance }{ }^{*} \text { middle-income } \\
\text { group }\end{array}$ & $\begin{array}{c}0.054 \\
(0.045)\end{array}$ & $\begin{array}{l}-0.111 \\
(0.091)\end{array}$ & $\begin{array}{l}-0.024 \\
(0.045)\end{array}$ & $\begin{array}{l}-0.029 \\
(0.039)\end{array}$ \\
\hline Urban pension insurance ${ }^{*}$ high income group & $\begin{array}{l}-0.003 \\
(0.071)\end{array}$ & $\begin{array}{c}0.001 \\
(0.139)\end{array}$ & $\begin{array}{c}0.046 \\
(0.071)\end{array}$ & $\begin{array}{c}0.012 \\
(0.062)\end{array}$ \\
\hline Log of average monthly income & $\begin{array}{l}-0.020 \\
(0.019)\end{array}$ & $\begin{array}{l}0.225^{* * *} \\
(0.042)\end{array}$ & $\begin{array}{l}0.073^{* * *} \\
(0.019)\end{array}$ & $\begin{array}{l}0.051^{* * *} \\
(0.017)\end{array}$ \\
\hline Other control variables & controlled & controlled & controlled & controlled \\
\hline Observations & 3315 & 3315 & 3315 & 3315 \\
\hline R-squared & 0.102 & 0.130 & 0.072 & 0.094 \\
\hline
\end{tabular}

Notes: Robust standard errors are put into parentheses; ${ }^{* * *}$ indicates significance at $1 \%$ level, ${ }^{* *}$ at $5 \%$ level and ${ }^{*}$ at $10 \%$ level.

pension insurance in different area because of job conversion. For migrant workers more than 45 years old, due to their mobility, it is difficult for them to meet the requirement that they have paid cumulative contributions for more than 15 years and have paid contributions for more than 10 years in the same place of employment. Therefore, according to the normal retirement age of 60 in China, the migrant workers above the age of 45 participate in the urban pension insurance, their expectations of future pension are relatively low, while those less than the age of 45 have a higher expectation of future pension. The impact of urban pension insurance on the total consumption of migrant workers varies accordingly in different age groups. However, it is possible that there is no significant heterogeneity in the effects of different age groups of migrant workers on the food consumption.

In this paper, migrant workers are grouped in the age of $45 . \mathrm{D}_{2 \mathrm{i}}=1$ means migrant workers over the age of 45 , and $D_{2 i}=0$ means migrant workers under the age of 45. The model is set as follows:

$$
\ln C_{j i}=\beta_{0}+\gamma D_{i}+\eta D_{i} \cdot D_{2 i}+\beta_{1} \ln X_{1 i}+\sum_{k=2} \beta_{k} X_{k i}+w_{i}
$$

Table 4 reports the estimated results. The interactions with urban pension insurance and migrant workers over the age of 45 is not statistically significant, indicating that there is no significant heterogeneity in the impact of urban pension insurance on the intake of carbohydrate, fat, protein and calorie of migrant workers in different age groups.

Table 4 - Estimation results of model (4).

\begin{tabular}{|c|c|c|c|c|}
\hline Variables & Carbohydrate & Fat & Protein & Calorie \\
\hline Urban pension insurance & $\begin{array}{c}0.024 \\
(0.023)\end{array}$ & $\begin{array}{l}0.131^{* * *} \\
(0.047)\end{array}$ & $\begin{array}{l}0.077^{* * *} \\
(0.023)\end{array}$ & $\begin{array}{l}0.065^{* * *} \\
(0.021)\end{array}$ \\
\hline $\begin{array}{l}\text { Urban pension insurance }{ }^{*} \\
\text { above } 45 \text { years old }\end{array}$ & $\begin{array}{c}0.013 \\
(0.051)\end{array}$ & $\begin{array}{c}0.022 \\
(0.103)\end{array}$ & $\begin{array}{c}0.058 \\
(0.048)\end{array}$ & $\begin{array}{c}0.015 \\
(0.044)\end{array}$ \\
\hline Log of average monthly income & $\begin{array}{l}-0.019 \\
(0.018)\end{array}$ & $\begin{array}{l}0.222^{* * *} \\
(0.039)\end{array}$ & $\begin{array}{l}0.076^{* * *} \\
(0.019)\end{array}$ & $\begin{array}{l}0.051^{* * *} \\
(0.016)\end{array}$ \\
\hline Other control variables & controlled & controlled & controlled & controlled \\
\hline Observations & 3315 & 3315 & 3315 & 3315 \\
\hline$R$-squared & 0.102 & 0.130 & 0.072 & 0.094 \\
\hline
\end{tabular}

Notes: Robust standard errors are put into parentheses; ${ }^{* * *}$ indicates significance at $1 \%$ level, ${ }^{* *}$ at $5 \%$ level and ${ }^{*}$ at $10 \%$ level.

Ciência Rural, v.51, n.12, 2021. 


\section{Endogenous test}

Migrant workers can voluntarily choose whether to participate in urban pension insurance. However, this selection is not random, and endogenous problems may occur accounting for the following reason. First, under the arrangement of China's urban pension insurance system, whether migrant workers participate in urban pension insurance depends largely on their employers. From the perspective of the enterprises, the social security fee is an important part of the cost of enterprise management. Thus, even though the local governments require enterprises to provide urban pension insurance for migrant workers with labor contracts, they still avoid participating in urban pension insurance and paying for it. Second, from the perspective of migrant workers, the relatively low-income restricts the effective demand of migrant workers for pension insurances, most of them pay more attention to improve the current income level rather than social security for lacking of the awareness of social security. In addition, insurance relationships are difficult to be changed. The procedure of "premium returns" is red-tape, which also affects the enthusiasm of migrant workers to participate in the urban pension insurance (YANG \& GUO, 2016). Due to the above two reasons can't observe, then it will cause model (2) $\operatorname{Cov}(D, u) \neq 0$, and will make OLS estimate biased and inconsistent.

Heckit model (HECKMAN, 1979) is used to test the endogeneity of urban pension insurance. The model consists of the result model (5) and the selection model (6), and the advantage is that it is not necessary to introduce instrumental variables into the selection model (6), but it is assumed that the error terms of the model (5) and (6) follow the normal distribution (CERULLI, 2015).

$$
\begin{gathered}
\ln C_{j i}=\beta_{0}+\gamma D_{i}+\beta_{1} \ln X_{1 i}+\sum_{k=2} \beta_{k} X_{k i}+u_{i} \\
D_{i}^{*}=\alpha_{0}+\alpha_{1} \ln X_{1 i}+\sum_{k=2} \alpha_{k} X_{k i}+v_{i}, \begin{cases}D_{i}=1, & D_{i}^{*} \geqslant 0 \\
D_{i}=0, & D_{i}^{*}<0\end{cases} \\
\operatorname{Cov}\left(u_{i} ; v_{i}\right)=\rho
\end{gathered}
$$

Test $\mathrm{H}_{0}: \rho=0, \rho=\operatorname{Cov}\left(\mathrm{u}_{\mathrm{i}} ; \mathrm{v}_{\mathrm{i}}\right)$, determines the endogeneity of $D$, and makes null assume that $D$ is exogenous. Full Maximum Likelihood method is used to estimate the Heckit model. Test results reported in table 5, and the first column shows the results of the carbohydrate model: $\chi^{2}(1)=0.40, \mathrm{p}\left[\chi^{2}(1)>0.40\right]=0.52$, accepting the null hypothesis, which indicates that $D$ in the carbohydrate model is exogenous. The fat, protein, and calorie models have the same effect.

\section{Robustness check}

Matching method that relaxes the assumption of function form and controls observable factors by the nonparametric method. When covariate of the treated group and the control group are quite different, regression analysis generally cannot present a robust estimation for it is very sensitive to the form of model functions. By the way of matching the observed samples with unbalanced covariates and separating the samples with relatively balanced covariates, the estimation results of the matching method are usually more robust, and it is not sensitive to the functional form (ZHAO, 2015). Therefore, the influence of urban pension insurance is further estimated by the Propensity Score Matching (PSM) method to test the robustness of OLS estimation.

Steps of PSM: Firstly, the Logit model is used to estimate the Propensity Index.

$$
\ln \left[\frac{p\left(D_{i}=1\right)}{1-p\left(D_{i}=1\right)}\right]=\alpha_{0}+\sum_{k=1} \alpha_{k} X_{k i}+v_{i}
$$

Factors affecting independent variables (Urban pension insurance) and dependent variables (nutritional intake of migrant workers) should be matched as covariables (ZHAO, 2015). Therefore, in this paper, the control variables of model (2) are introduced as the covariables of model (7), and the Propensity Index $p\left(D_{i}=1\right)$ is estimated for each migrant worker. Next, The similar Propensity Index in the treatment group(those who participate in urban pension insurance) and the control group (those who do not participate in urban pension insurance)

Table 5 - Endogenous test of urban pension insurance variables.

\begin{tabular}{lccc}
\hline Carbohydrate & Fat & Protein & Calorie \\
\hline $\mathrm{H}_{0}: \rho=0$ & $\mathrm{H}_{0}: \rho=0$ & $\mathrm{H}_{0}: \rho=0$ & $\mathrm{H}_{0}: \rho=0$ \\
$\rho=-0.054$ & $\rho=-0.044$ & $\rho=-0.053$ & $\rho=-0.054$ \\
$\chi^{2}(1)=0.40$ & $\chi^{2}(1)=0.09$ & $\chi^{2}(1)=0.22$ & $\chi^{2}(1)=0.24$ \\
$p\left[\chi^{2}(1)>0.40\right]=0.52$ & $p\left[\chi^{2}(1)>0.09\right]=0.77$ & $p\left[\chi^{2}(1)>0.22\right]=0.64$ & $p\left[\chi^{2}(1)>0.24\right]=0.62$ \\
accept the null hypothesis & accept the null hypothesis & accept the null hypothesis & accept the null hypothesis \\
\hline
\end{tabular}

Ciência Rural, v.51, n.12, 2021. 
were matched to make the distribution of each covariable balanced between the two groups. Then, the standardized mean difference index is used to test the balance of the covariables of the two groups of samples, and the formula is as follows:

$$
\Delta \bar{X}_{t c}=\frac{\bar{X}_{t}-\bar{X}_{c}}{\sqrt{\left(S_{t}^{2}+S_{c}^{2}\right) / 2}}
$$

wnere, $\bar{X}_{t}$ and $\bar{X}_{c}$ respectively represent the mean value of covariables of migrant workers in the treatment group and the control group. $S_{t}^{2}$ and $S_{c}^{2}$ respectively represent the sample variances of the covariates in the treatment group and the control group. As shown in figure 1, only a few control groups' Propensity Index is not within the common value range, which means that only a small number of samples will be lost in the Propensity Index matching. According to the results reported in table 6, after all variables are matched, the $t$ test results do not reject the null hypothesis that there is no systematic difference between the treatment group and the control group, which indicates that the estimated Propensity Index satisfies the characteristics of the equilibrium index.

This paper employed the nearest-neighbor matching, radius matching and nuclear matching to estimate the effect of urban pension insurance. Based on the estimated results in table 7, urban pension insurance has no significant influence on the carbohydrate intake of migrant workers, which is consistent with OLS estimation. Urban pension insurance has a significant positive effect on the intake of fat, protein and calories of migrant workers, and its effects ranging from 0.145 to $0.155,0.081$ to 0.083 and 0.065 to 0.067 respectively. No matter statistical significance or size, the effect of urban pension insurance is consistent with OLS estimation. The above conclusions indicate that OLS estimates are robust.

\section{DISCUSSION AND CONCLUSION}

Urban pension insurance can reduce future uncertainty, reducing precautionary savings for migrant workers and promoting current consumption. There is a low attendance for migrant workers in middle and low-income groups. Social insurance can help migrant workers improve their nutritional intake structure. First, this paper sheds theoretical light on the relationship between urban pension insurance and nutritional intake of migrant workers. It explores empirically the impact of urban pension insurance on the nutritional intake structure of migrant workers using survey data from China Agricultural University's "Employment and Food Demand of Urban Migrant Workers." Results showed that urban pension insurance changes the nutritional intake structure of migrant workers, and fat as well as fat protein replaces carbohydrates as the main nutrient.

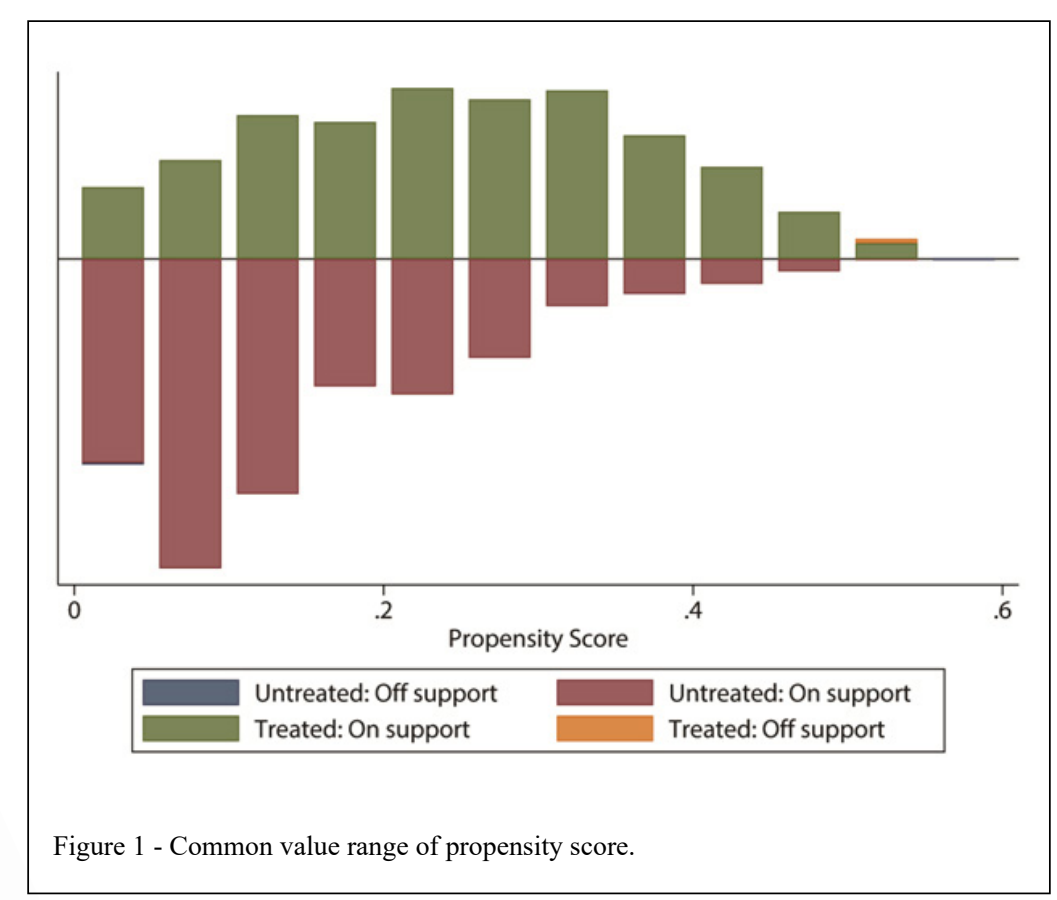

Ciência Rural, v.51, n.12, 2021. 
Table 6 - Balance test after matching.

\begin{tabular}{|c|c|c|c|c|c|c|}
\hline \multirow[t]{2}{*}{ Variables } & & \multicolumn{2}{|c|}{ Mean } & \multirow[t]{2}{*}{$\begin{array}{l}\text { Standardized mean difference } \\
(\%)\end{array}$} & \multirow[t]{2}{*}{$\begin{array}{l}\text { Reduction in absolute value } \\
\text { standardized difference }(\%)\end{array}$} & \multirow[t]{2}{*}{$\mathrm{T}$ value } \\
\hline & & Treated & Control & & & \\
\hline \multirow{2}{*}{$\begin{array}{l}\text { Ln monthly } \\
\text { income }\end{array}$} & $\mathrm{U}$ & 7.9259 & 7.9911 & -14.5 & & $-3.03^{* * *}$ \\
\hline & M & 7.9262 & 7.9279 & -0.4 & 97.5 & -0.06 \\
\hline \multirow{2}{*}{ Gender } & $\mathrm{U}$ & 0.53916 & 0.59328 & -10.9 & & $-2.35^{* *}$ \\
\hline & M & 0.53931 & 0.55096 & -2.4 & 78.5 & -0.39 \\
\hline \multirow{2}{*}{ Age } & $\mathrm{U}$ & 35.559 & 35.896 & -3.2 & & -0.65 \\
\hline & M & 35.547 & 35.352 & 1.8 & 42.3 & 0.32 \\
\hline \multirow{2}{*}{ Age square } & $\mathrm{U}$ & 1362.3 & 1416.7 & -6.7 & & -1.37 \\
\hline & M & 1361.7 & 1348.8 & 1.6 & 76.4 & 0.28 \\
\hline \multirow{2}{*}{ BMI } & $\mathrm{U}$ & 22.122 & 22.256 & -4.3 & & -0.94 \\
\hline & M & 22.122 & 22.106 & 0.5 & 88.2 & 0.09 \\
\hline \multirow{2}{*}{$\begin{array}{l}\text { High school or } \\
\text { junior college }\end{array}$} & $\mathrm{U}$ & 0.44627 & 0.27585 & 36.0 & & $8.00^{* * *}$ \\
\hline & M & 0.44607 & 0.46694 & -4.4 & 87.8 & -0.69 \\
\hline \multirow{2}{*}{$\begin{array}{l}\text { Bachelor and } \\
\text { above }\end{array}$} & $\mathrm{U}$ & 0.08015 & 0.03145 & 21.3 & & $5.37^{* * *}$ \\
\hline & M & 0.07861 & 0.07827 & 0.2 & 99.3 & 0.02 \\
\hline \multirow{2}{*}{$\begin{array}{l}\text { Middle manual } \\
\text { labour }\end{array}$} & $\mathrm{U}$ & 0.69217 & 0.54194 & 31.3 & & $6.53^{* * *}$ \\
\hline & M & 0.69104 & 0.68106 & 2.1 & 93.4 & 0.36 \\
\hline \multirow{2}{*}{$\begin{array}{l}\text { Heavy manual } \\
\text { labour }\end{array}$} & U & 0.0929 & 0.30694 & -55.5 & & $-10.47^{* * *}$ \\
\hline & M & 0.09324 & 0.10367 & -2.7 & 95.1 & -0.58 \\
\hline \multirow{2}{*}{ Guang Dong } & $\mathrm{U}$ & 0.27322 & 0.18619 & 20.8 & & $4.67^{* * *}$ \\
\hline & M & 0.27422 & 0.26827 & 1.4 & 93.2 & 0.22 \\
\hline \multirow{2}{*}{ Shan Dong } & $\mathrm{U}$ & 0.2204 & 0.19812 & 5.5 & & 1.19 \\
\hline & M & 0.22121 & 0.21314 & 2.0 & 63.8 & 0.32 \\
\hline \multirow{2}{*}{ Si Chuan } & $\mathrm{U}$ & 0.25865 & 0.18547 & 17.7 & & $3.94^{* * *}$ \\
\hline & M & 0.25594 & 0.27146 & -3.7 & 78.8 & -0.58 \\
\hline \multirow{2}{*}{ Zhe Jiang } & $\mathrm{U}$ & 0.13479 & 0.22343 & -23.3 & & $-4.68^{* * *}$ \\
\hline & M & 0.13528 & 0.13053 & 1.2 & 94.6 & 0.23 \\
\hline
\end{tabular}

Notes: U represent Unmatched, M represent Matched.

Following controlled factors such as monthly average income and labor intensity for migrant workers, urban pension insurance significantly improves fat and protein intake by $13.5 \%$ and $8.8 \%$ respectively, but has no significant effect on the intake of carbohydrate. Their calorie intake increased by $6.8 \%$ due to changes in migrant workers' nutritional intake structure. This result is consistent with that of Ma and ZHANG (2011). Heterogeneity analysis showed no significant difference in the effect of urban pension insurance on the calorie intake of migrant workers at different income levels and different age groups. In addition, income has a significant positive effect on migrant workers' calorie, fat and protein intake, but no significant effect on carbohydrate intake. The government should strictly enforce the law and truly implement the mandatory requirements of urban pension insurance, reduce the behaviors of enterprises evading insurance participation and payment, and increase the participation rate of urban pension insurance for migrant workers, which is conducive to stimulating their urban consumption and improving their nutritional intake.

From the perspective of food consumption; although, few studies have directly examined the relationship between public pension and residents' nutritional intake structure, most previous studies support our findings that participation in pension insurance can reduce the future uncertainty faced by residents and promote nutrition consumption in the current period (ZHENG \& ZHONG, 2016; ZHAO, 2018). However, there are some differences in different age groups. Our study showed that participating in the urban pension insurance can promote the nutritional intake of migrant workers over 45 years old, while the study of HUANG (2016) 
Table 7 - Estimation results of propensity score matching method.

\begin{tabular}{|c|c|c|c|c|}
\hline \multirow[t]{2}{*}{ Variables } & \multirow[b]{2}{*}{ Carbohydrate } & \multirow[t]{2}{*}{ e influen } & \multirow[b]{2}{*}{ Protein } & \multirow[b]{2}{*}{ Calorie } \\
\hline & & & & \\
\hline The nearest neighbour matches & $\begin{array}{c}0.020 \\
(0.029)\end{array}$ & $\begin{array}{l}0.155^{* *} \\
(0.074)\end{array}$ & $\begin{array}{l}0.082^{* *} \\
(0.034)\end{array}$ & $\begin{array}{l}0.067^{* *} \\
(0.029)\end{array}$ \\
\hline Radius matching & $\begin{array}{c}0.014 \\
(0.026)\end{array}$ & $\begin{array}{l}0.146^{* *} \\
(0.063)\end{array}$ & $\begin{array}{l}0.081^{* * *} \\
(0.028)\end{array}$ & $\begin{array}{l}0.065^{* *} \\
(0.026)\end{array}$ \\
\hline Nuclear matching & $\begin{array}{c}0.014 \\
(0.026)\end{array}$ & $\begin{array}{l}0.145^{* *} \\
(0.061)\end{array}$ & $\begin{array}{l}0.083^{* * *} \\
(0.029)\end{array}$ & $\begin{array}{l}0.065^{* *} \\
(0.026)\end{array}$ \\
\hline OLS & $\begin{array}{c}0.026 \\
(0.021)\end{array}$ & $\begin{array}{l}0.135^{* * *} \\
(0.043)\end{array}$ & $\begin{array}{l}0.088^{* * *} \\
(0.021)\end{array}$ & $\begin{array}{l}0.068^{* * *} \\
(0.019)\end{array}$ \\
\hline
\end{tabular}

Notes: Robust standard errors are put into parentheses; ${ }^{* * *}$ indicates significance at $1 \%$ level, ${ }^{* *}$ at $5 \%$ level and ${ }^{*}$ at $10 \%$ level; Calculated by self-help method, and the number of sampling is 200 .

shows that household consumption of residents aged 45-60 years old participating in the new rural insurance is squeezed to a certain extent due to their pension contributions, with the most significant impact on family food expenditure.

In this study, the following deficiencies included: first; although, this paper uses the Heckit model to examine endogenous variables, the results show that there is not endogenous problem, but it is assumed that the error terms of the model (5) and (6) follow the normal distribution (CERULLI, 2015). However, this paper does not examine whether this requirement is met, therefore, the results may be lack of robustness.

Second, there may be measurement errors in the nutritional intake data of migrant workers. In the survey data of "Employment and Food Demand of urban Migrant workers", the daily nutrition intake of migrant workers is calculated based on the food consumption data in a day, thus the daily nutrition intake of migrant workers measured may have some accidental deviation.

Third, food price is an important factor affecting residents' nutritional intake. In the survey data of "Employment and Food demand of urban migrant workers", there is a lack of food price data in the surveyed place. Therefore, this paper uses regional dummy variables to approximate control regional food prices .

Most importantly, some policy implications can be derived from the empirical analysis. It is more effective to participate in urban pension insurance for increasing the nutrition intake of migrant workers than increasing their income. Increasing the coverage of urban pension insurance in urban areas will improve the nutrition intake of migrant workers. First, the government should strictly enforce related laws, truly implement the mandatory requirement that enterprises should pay urban pension insurance for migrant workers, and improve the situation of enterprises evading participation and payment. Second, optimizing the account management and payment period of urban pension insurance to adapt to the different characteristics of migrant workers, strive to implement the national pooling account as soon as possible, and completely deal with the transferable problems of insurance relationship. Thirdly, optimizing the operating environment of the urban pension insurance system for migrant workers, strengthening the cooperation among regions, created sound conditions for transfering migrant workers' insurance relations. It is reasonable that providing simplified the procedures for migrant workers for transferring insurance relationship so as to effectively solve the problem of difficult migration of insurance relationship and further protect the enthusiasm of migrant workers to participate in urban pension insurance.

\section{ACKNOWLEDGEMENTS}

We would like to thank two anonymous reviewers and the editor of this journal for their useful comments and suggestions. This work was fnancially supported by the National Natural Science Foundation of China (Grant number: 71673316).

\section{DECLARATION OF CONFLICT OF INTEREST}

The authors declared no potential conflicts of interest with respect to the research, authorship, and/or publication of this article. 


\section{AUTHORS' CONTRIBUTIONS}

Zhipeng He \& Ye Deng were fully engaged in writing the manuscript and was also fully involved in paper revision. Lei $\mathrm{Li}$ performed data analysis and was involved in paper revision. Kang Yu provided supervision and support for the completion of the paper.

\section{REFERENCES}

CERULLI, G. Econometric evaluation of socio-economic programs: Theory and applications. Heidelberg: Springer, 2015. Available from: <https://link.springer.com/book/10.1007/978-3-662-46405-2>. Accessed: Sep. 5, 2020. doi: 10.1007/978-3-662-46405-2_2.

CHINESE SOCIETY OF NUTRITION. Dietary nutrient reference intake of Chinese residents (2013 Edition). Beijing: Science Press, 2014. (In Chinese).

HAN, Z. Y.; et al. A study on the causes of poverty caused by urban migrant workers in China: Based on the micro-survey of Beijing, Shenzhen and Huizhou. Journal of Demography, v.39, n.3, p.5265, 2017. (In Chinese).

HECKMAN, J J. Sample Selection bias as a specification error Journal of the Econometric Society. n.47, p.153-161, 1979. Available from: <https://www.semanticscholar.org/paper/Sampleselection-bias-as-a-specification-error-Heckman/70183fe2bab484 cd26d2a9146345f871bdd29115>. Accessed: Aug. 26, 2008. doi: $10.2307 / 1912352$.

HUANG, R. The effects of the new rural social pension insurance on old aging farmers' household consumption: evidence from 2011-2013 CHARLS. Reform of Economic System, n.6, p.84-92, 2016. (In Chinese).

HUBBARD, R. G.et al. Precautionary saving and social insurance. Journal of Political Econ-omy, v.103, n.2, p.360-399, 1995 Available from: <http://dx.doi.org/10.1086/261987>. Accessed: Apr. 12, 1995. doi: 10.1086/261987.

LI, G. J.; CHEN, Y. F. Analysis of the impact of income growth on nutrition demand-- evidence from urban households in Guangdong Province. Economic Science, n.3, p.60-72, 2017. (In Chinese).

LI, G. J. et al. Income growth, household registration differences and nutrition consumption-- A study based on migrant workers' families in cities. Agricultural Technology and economy, n.10, p.66-76, 2018b. (In Chinese).

LI, J. M. et al. From health advantage to health disadvantage: The epidemiological paradox in rural migrants. Population Research, v.42 n.6, p.46-60, 2018a. (In Chinese).

LI, L. Study on the food and nutrition demand and dietary health of rural-urban migrants. Beijing: China Agricultural University, 2020. (In Chinese).

LI, P. L.; LI, W. The economic status and social attitude of migrant workers in China's transition. Sociological Studies, n.3, p.1-17, 2007. (In Chinese).

LI, Y. S. Effect of household income risk on nutrition intake of Chinese rural residents. Southern Economy, n.10, p.200-213, 2012. (In Chinese).
LI, Z. M. Changing characteristics of food consumption and nutrition development of Chinese residents in recent 50 years. Resource Science, n.1, p.27-35, 2007. (In Chinese).

LU, W. C.; LI, Y. L. Theoretical reasoning on health rights of migrant workers: A perspective of environmental justice. Chinese Journal of Population Science, n.3, p.13-20, 2009. (In Chinese).

MA, S. et al. Analysis of the influence of new rural cooperative medical insurance on food consumption of rural residents. Economics (Quarterly), v.10, n.1, p.249-270, 2011. (In Chinese).

MA, S.; ZHANG, K. New rural cooperative medical insurance and the improvement of residents' nutritional structure. Economic Research, v.46, n.5, p.126-137, 2011. (In Chinese).

MENG, X. et al. Impact of Income Growth and Economic Reform on Nutrition Availability in Urban China:1986-2000. Economic Development and Cultural Change, n.2, p.261295, 2009. Available from: <https://www.journals.uchicago. edu/doi/10.1086/592838>. Accessed: Mar. 19, 2018. doi: $10.1086 / 592838$.

STRAUSS, J. Does better nutrition raise farm productivity? Journal of Political Economy, v.94, n.2, p.267-320, 1986. Available from: $<$ https://www.journals.uchicago.edu/doi/abs/10.1086/261375>. Accessed: Apr. 14, 1986. doi: 10.1086/261375.

WANG, Y; HE, X. R. How does education produce health benefits?: Evidence from the perspective of food and nutrition intake. Journal of Northwestern Polytechnic University (Social Science Edition), v.36, n.3, p.37-43, 2016. (In Chinese).

WANG, Z. H. et al. Medical System and Nutrition Improvement for the Rural Elderly. Journal of Health, Population and Nutrition, v.38, n.1, p.1-10, 2019. Available from: <https://doi.org/10.1186/ s41043-019-0189-x>. Accessed: Oct. 18, 2019. doi: 10.1186/ s41043-019-0189-x.

YANG, C. Y; GUO, J. F. The predicament and theoretical explanation of the operation of peasant workers' pension insurance system. Journal of Zhejiang University (Humanities and Social Sciences), n.3, p.108-116, 2016. (In Chinese).

ZHAO, T. Impacts of endowment insurance on migrant workers' urban consumption: An analysis based on consumption level and consumption structure. Journal of Jiangxi University of Finance and Economics, n.3, p.77-85, 2018. (In Chinese).

ZHAO X. L. Propensity index matching method: variable selection and model setting. Research on Quantitative Economy, Technology and Economy, v.32, n.11, p.133-147, 2015. (In Chinese).

ZHENG, H. M.; ZHONG T. The impacts of social pension on rural household expenditure: evidence from China. Journal of Economic Policy Reform. v.19, n.3, p.221-237, 2016. Available from: $<$ https://www.tandfonline.com/doi/abs/10.1 080/17487870.2015.1041524>. Accessed: Jun. 2, 2015. doi: $10.1080 / 17487870.2015 .1041524$.

ZHENG, Z. H.; HENNEBERRY, S. R. Estimating the Impacts of Rising Food Prices on Nutrient Intake in Urban China. China Economic Review, n.4, p.1090-1103, 2012. Available from: $\quad<$ https://www.sciencedirect.com/science/article/abs/pii/ S1043951X12000636>. Accessed: Jul. 20, 2012. doi: 10.1016/j. chieco.2012.07.001. 